\title{
Powering Progress with Evidence: Annual Report 2017
}

Population Council

Follow this and additional works at: https://knowledgecommons.popcouncil.org/

series_newsletters_annualreports

How does access to this work benefit you? Let us know!

\section{Recommended Citation}

"Powering Progress with Evidence: Annual Report 2017." New York: Population Council, 2018. 


\section{WHY QUALITY EVIDENCE MATTERS}

The Population Council is at the forefront of research, policy analysis, and program design in low- and middle-income countries. In the last year, our research has highlighted the importance of investing in girls early, before irreversible life events anchor them in poverty, and illuminated the influence of inequitable gender norms in accessing HIV/AIDS services. Our research has illustrated the critical role of quality of care in addressing sexual and reproductive health needs, and much more.

RESEARCH SPOTLIGHT: CATALYZING PROGRESS Young people are powerful catalysts for social and economic development and change. In Bihar and Uttar Pradesh, two populous states in India where more than $6 \%$ of the world's adolescents live, the Understanding the Lives of Adolescents and Young Adults (UDAYA) survey offers the first state

representative data of its kind among 10-14-year-

old boys and girls. Combining longitudinal as well

successive cross-sectional data from more than

20,000 a conts, the study reveals new insights

into the inclusion, and health.

These unique data reveal that since 2007:

Health progress

- The vast majority of older adolescents now

deliver their first child in health facilities in both

states

- Sexual violence has declined by $30 \%$ among

married adolescent girls in Bihar

Social progress

- Child marriage is on the decline, with rates of early marriage dropping by one-third in Bihar and one-half in Uttar Pradesh

- More children are in school, including nearly $90 \%$ of younger girls (10-14) in both states

- Fewer adolescents are engaged in paid work in

both states

- Youth participation in political and civic life has improved in Bihar
Disparities continue

- Nearly $75 \%$ of girls and $62 \%$ of boys aged $10-14$ fluently or solve simple math - Among out-of-school adolescent girls, more than half have experienced early marriage

- As many as $70 \%$ of older adolescent boys have experienced physical violence from a parent

The UDAYA findings reinforce the importance of early interventions and offer a robust baseline from informing numerous health, early marriage, and economic interventions. The next round of data collection is in 2019.

CHALLENGING CONVENTION WITH RIGOR While interest and investment in programs for adolescent girls has grown, significant gaps remain in understanding what programs work, for which girls, under what circumstances, and at what cost. In fact, a recently published systematic review from In fact, a recently published systematic review from and 2014, only 77 rese an what works to improve the health were written th and well-being of adolescent girls.

Today, the Council is adding considerably to this body of research with dozens of randomized controlled trials and rigorous evaluations examining how to improve the lives of adolescent girls. Such evidence is critical to supporting prioritize investments in interventions backed by evidence and unlocking the potential of the next generation.

\section{GIRL Center}

\section{FOR INNOVATION, RESEARCH, AND LEARNING}

In 2017, the Population Council launched the Girl Innovation, Research, and Learning (GIRL) Center, a new global research center that generates, synthesizes, and translates
evidence to transform the lives of adolescent girls. Through rigorous research about what works - and what doesn't the Center helps direct which to measure progress. The research is already

QUESTIONS WE'RE ASKING ABOUT ADOLESCENT GIRLS

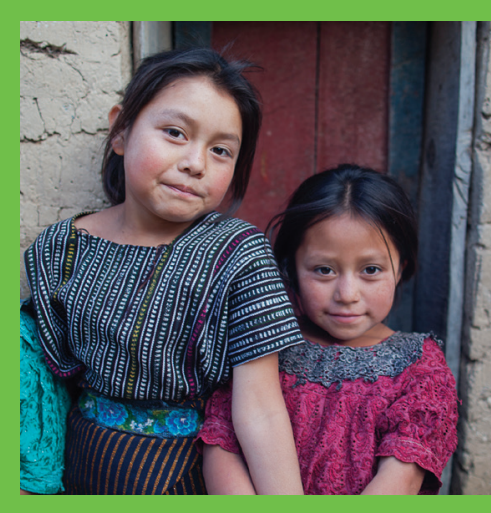

01

Can mentoring improve girls' health, education, and social

outcomes?

- Reaching 1,200

Mayan girls

- 2014-2018

\section{3}

What is the effect of health, wealth creation, education, and violence prevention interventions?

Adolescent Girls Initiative-

Reaching 5,000+ young adolescent girls in rural Wajir - 2013-2020

\section{5}

Can e-readers improve literacy outcomes for girls?

GirlsRead!, Zambia

- Reaching 1,200+ girls

- 2016-2018
Guaturidades,
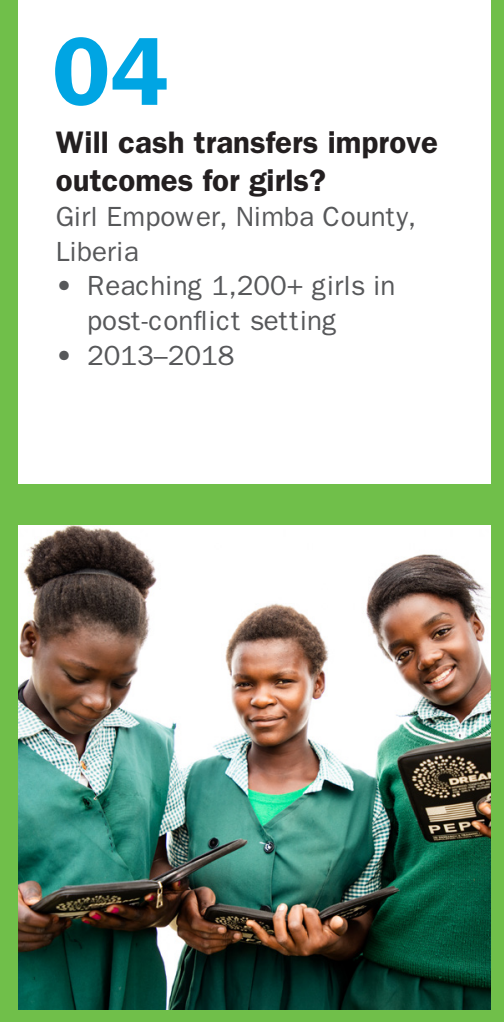

02

Do safe space programs improve the health and well-being of the most wullibe vulnerable girls? ( - Reaching 10,000 girls in in rural and urban settings - 2013-2018

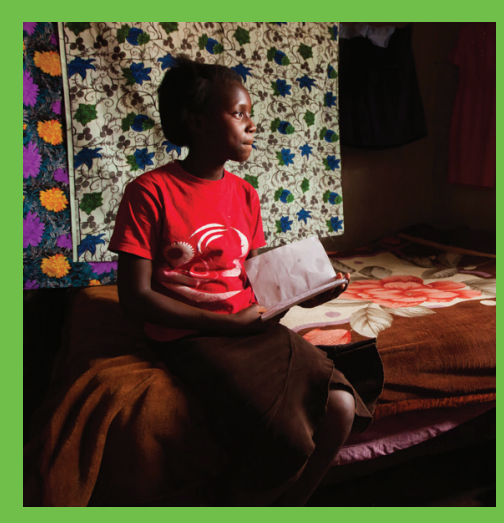

\section{6}

What is the effect of a community-based integrated services program on the well-being of girls living with HIV?

Project SOAR, Zambia

- Reaching $300+$ girls - 2015-2019

Girls Read! was funded in part by a grant from the United States Department of State as part of the DREAMS Innovation Challenge, managed by JSI Research \& Training Institute, Inc. (JSI). 


\section{ADVANCING BIOMEDICAL SOLUTIONS TO IMPROVE LIVES}

Since its founding in $\mathbf{1 9 5 6 ,}$ our Center for Biomedical Research (CBR) has conducted research and developed drugs, technologies, and products that enable women, men, and young people to protect and enhance their reproductive health and well-being.

Hundreds of millions of women-roughly a quarter of all women using contraceptives globally-are using a family planning method developed by the Population Council or based on our technologies. Today, our scientists are researching new

technologies and delivery systems to provide even greater choice and protection.

THE JOURNEY OF BIOMEDICAL RESEARCH Despite significant progress, about $40 \%$ of pregnancies are still unintended each year. Every day, more than 5,200 people become infected with HIV, disproportionately affecting girls and young women in pandemic regions. And more than one million people contract sexually transmitted

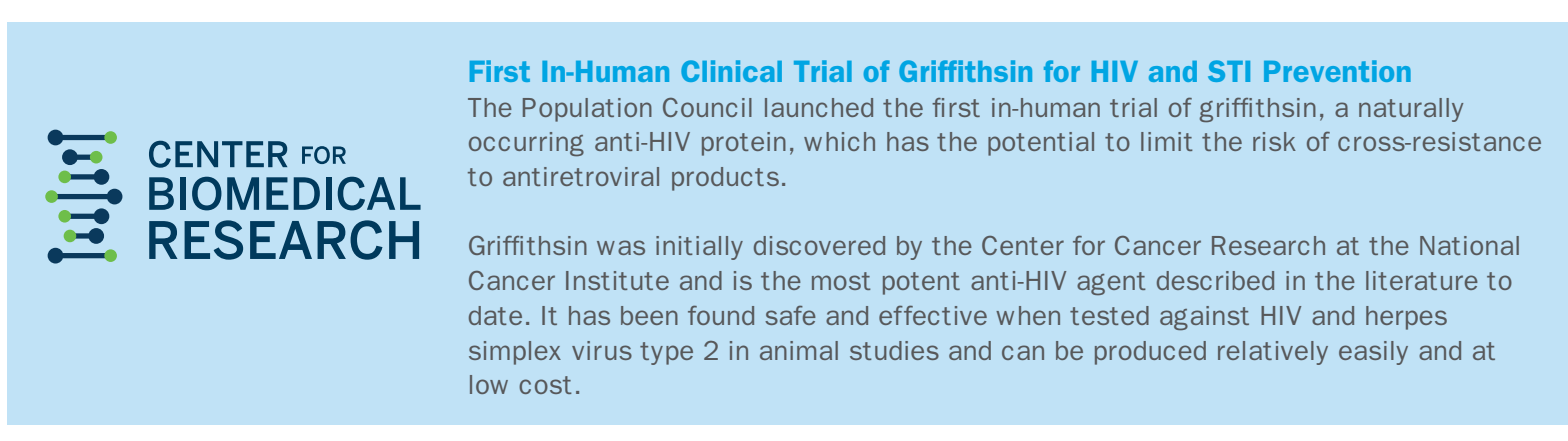

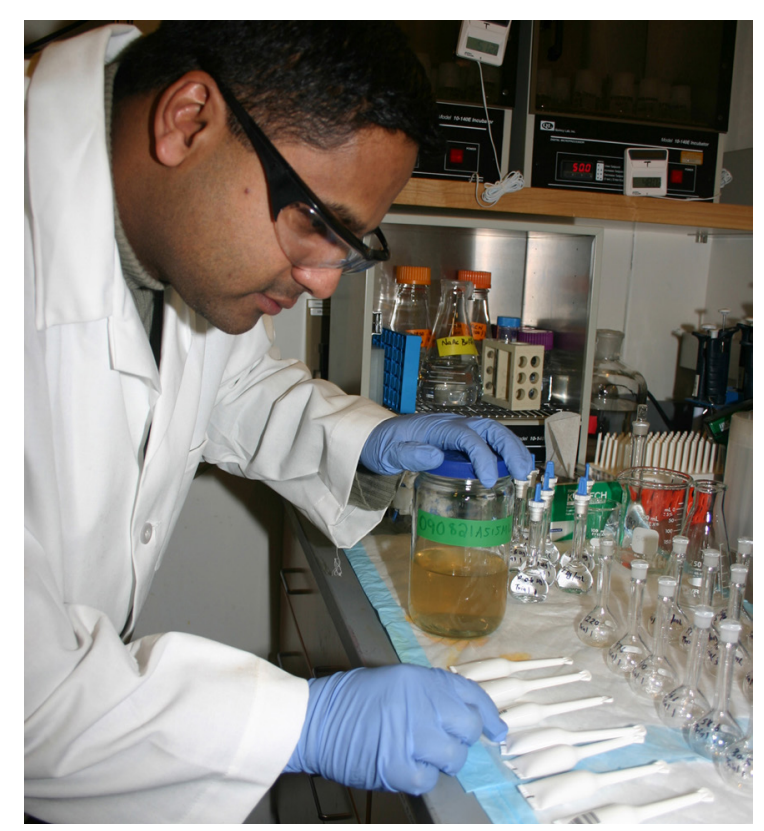

infections (STIS) that can cause cancer or infertility, complicate pregnancies, or increase the risk of infection with HIV.

While improving access to and quality of care can address some of the gaps, women and men also need more choice, convenience, and control in their contraception and STI-prevention methods.
ONE-YEAR

CONTRACEPTIVE

RING ADVANCES TO

U.S. FOOD AND DRUG

ADMINISTRATION

(FDA) REVIEW

MEETING WOMEN'S NEEDS

In the Phase III trials,

nearly 9 in 10 women

surveyed were satisfied

with the ring as a method

of contraception.

DATA FROM PHASE III 17 CLINICAL TRIALS

2,308 WOMEN, 27 STUDY SITES

If approved, the one-year contraceptive vaginal ring would be the first option to provide a full year of protection while completely under a woman's control. The does not require refrigeration and offers a quick return to fertility moved.

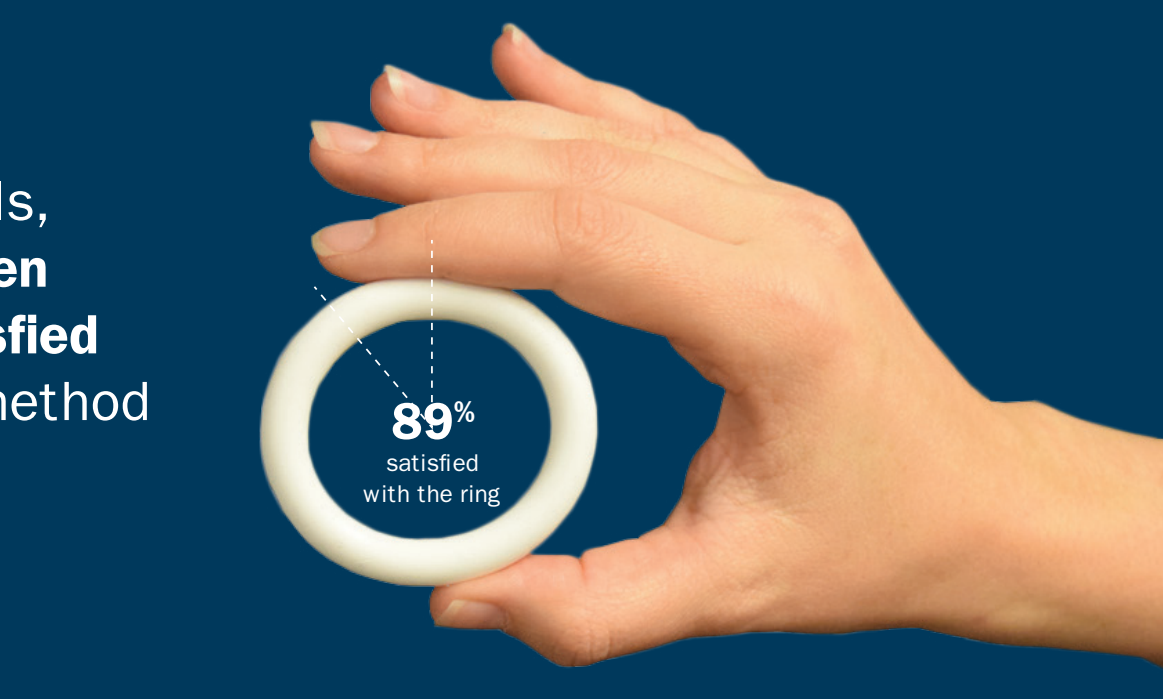

CHOICE, CONVENIENCE, AND CONTROL

Population Council researchers are developing innovative delivery systems that are designed to be safer, lower cost, and easier to use.

\begin{tabular}{|l|l|l|l|l}
\hline Vaginal rings & Gels & Fast-dissolving inserts & Microarray patch
\end{tabular}

Longer-acting methoc

$$
\text { Gels }
$$

Fast-dissolving inserts Microarray patch Topical gels applied to the Fast-dissolving tablets
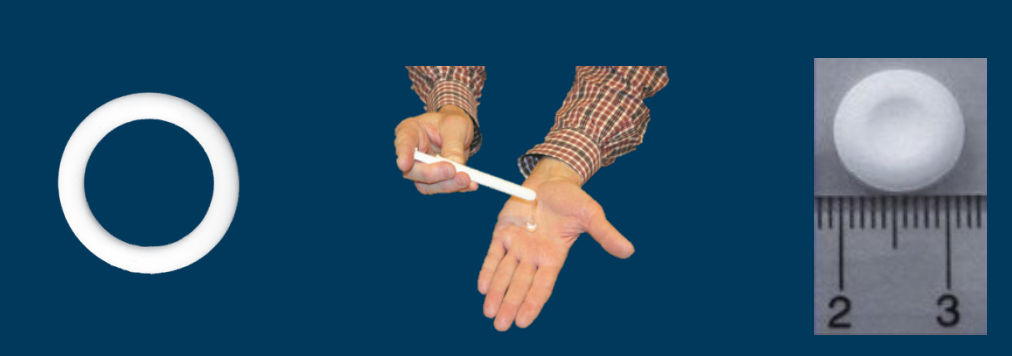

Discreet, self-use technology containing an array of tiny projection drug 28 layer of skin to deliver a

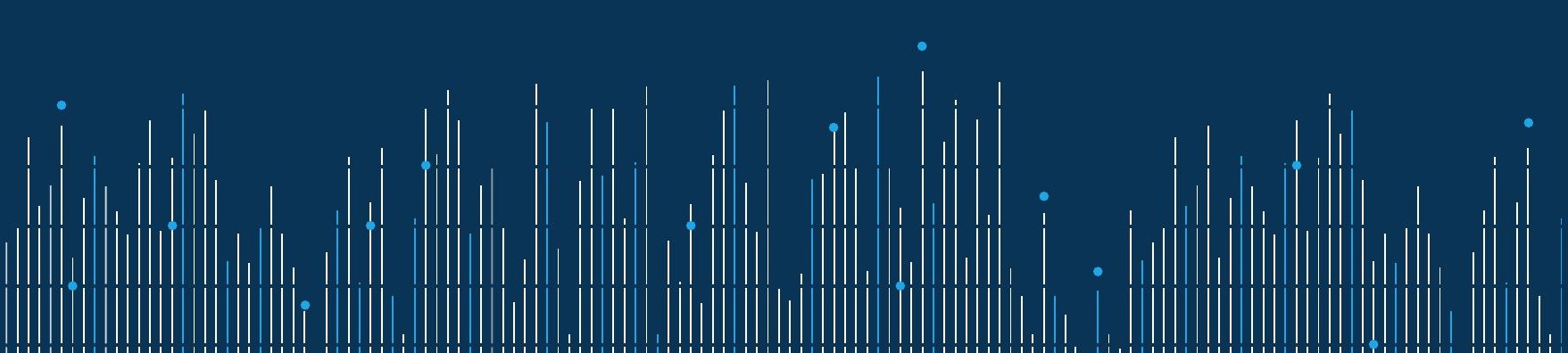


AROUND THE WORLD, governments and civil society organizations seek our help to understand and overcome obstacles to health and development.

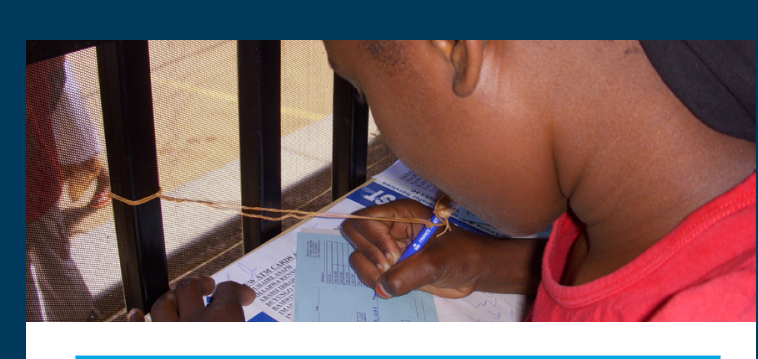

CAMEROON, UGANDA, SENEGAL

Addressing HIV stigma

The People Living with HIV (PLHIV) Stigma Index is the most widely used global survey of its kind. Administered by and for people living with HIV, the evidence generated has demonstrated the extent of stigma and its effects. Following shifts in the HIV epidemic and global response, Population
Council researchers are leading efforts to update the Index, including a three-country pilot, and
better reflect how key populations at risk of HIV are affected. The revised tool is now being implemented in nearly 20 countries worldwide.

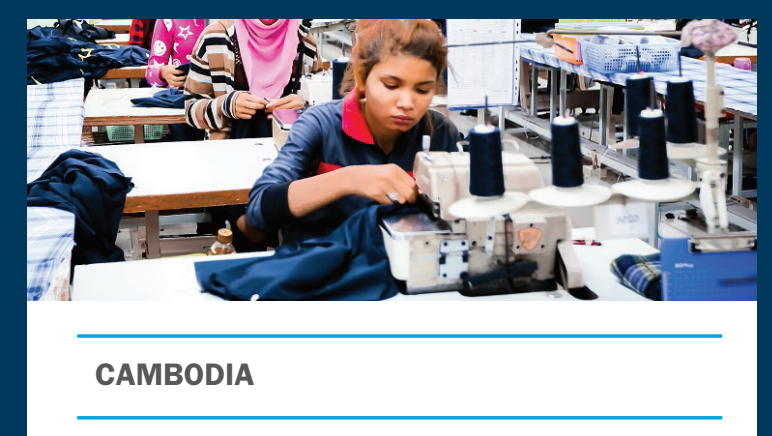

Promoting worker health

To help improve reproductive health for a largely (n) Cambodia, the Council led first-of-its-kind policy and research effort assessing the policy landscape, garment worker needs and living conditions, and outcomes of ongoing programs. The research galvanized efforts to prioritize reproductive health access, resulting in new Ministry of Labor and Vocational Training guidelines to include related services in workplace infirmaries. The project engaged with manufacturers and brands and promoted the use of evidence to improve the health of some 700,000 garment-sector workers.

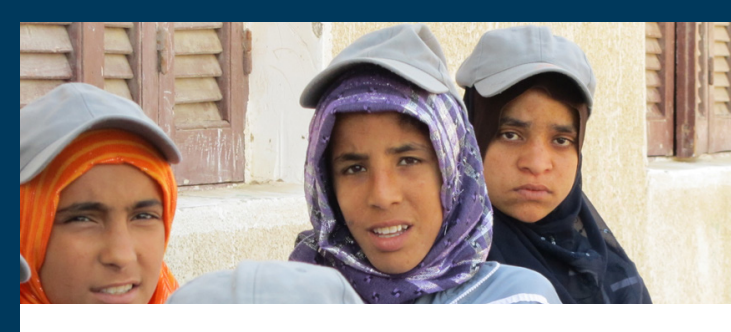

EGYPT

Evidence to end female genital mutilation/cutting The Population Council is leading a six-year multicountry research program to improve the evidence base on female genital mutilation/ cutting (FGM/C), a harmful cultural practice that involves cutting external female genitalia despite not having any health benefit. New evidence from Egypt found that nearly $40 \%$ of cases are now being performed by health care professionals. These findings led the National Population Counc in Egypt to approve integration of anti-FGM/C content into medical school curriculum that will be implemented in 17 public and 3 private
universities.

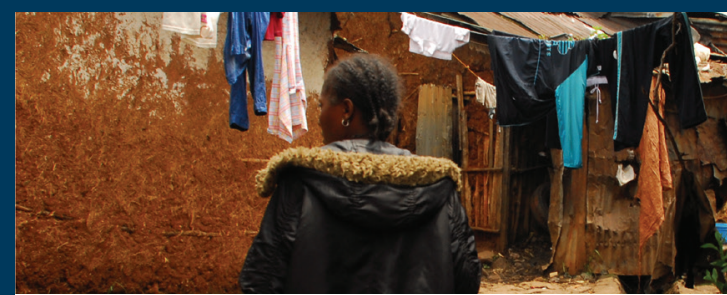

ETHIOPIA

Domestic work as pathway to sexual exploitation While the vast majority of child domestic workers
in Ethiopia are urban, Population Council research shows that most have migrated from rural areas, have lower education levels, and are more vulnerable to sexual abuse than nondomestic workers. A new study among 5,000+ urban and rural girls suggests domestic work is often an initial survival strategy and that young migrants frequently transition into other forms of workincluding a signific ant portion into sex work. The study reveals the need for additional support programs and increased attention to domestic forms of human trafficking.

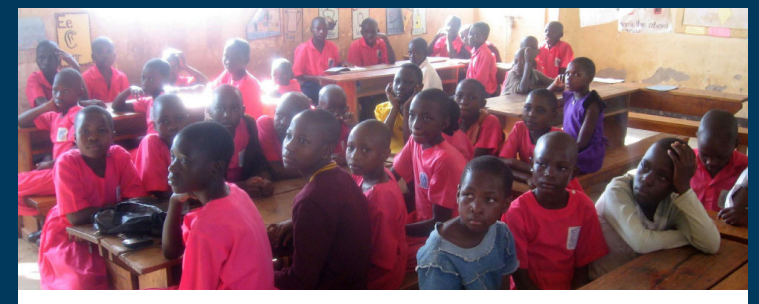

KENYA

Improving care for child survivors of sexual violence

The Council continues to work to improve care for child survivors through its Africa Regional Sexual and Gender-Based Violence Network. New studies found that half of children (49\%) in two Nairobi schools have experienced sexual violence and demonstrated that routine screening for violence against children is feasible and acceptable in both schools and health facilities when done by traine psychologists. Routine screening will now be pretested by the Ministry of Health, which has also adopted standard operating procedures that wimprove post rapecare services.

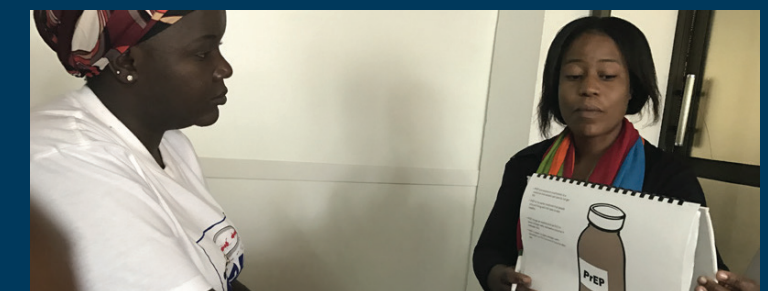

TANZANIA

Implementing PrEP for adolescents and young

women
Population Council researchers worked in collaboration with the Tanzanian National AIDS Control Programme to demonstrate the acceptability of, and identify opportunities for introducing oral pre-exposure prophylaxis (PrEP) for adolescent girls and young women. The study successfully garnered the perspectives of key stakeholder groups, including adolescent girls and young women, providers, parents, male partners, and policymakers. Study results are informing the Tanzanian national rollout of PrEP.

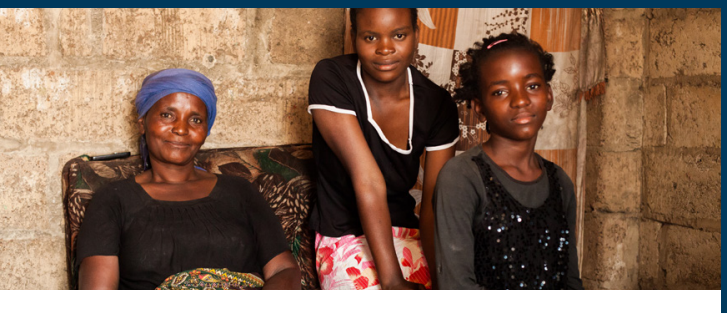

ZAMBIA

Identifying key populations

The Council conducted formative research to provide initial size estimates of key populations a risk for HIV in Zambia. Among female sex workers an integrated biological survey found HIV prevalence was about $50 \%$, three times higher than in the general population of women. Stigma and discrimination were found to be major barriers to HIV services. The findings have informed national HIV prevention, care, and treatment policies and programs, including Z ambia's National AIDS Strategic Framework, USAID's Country Operational Plan, 


\section{SHAPING THE PUBLIC AGENDA}

To have impact, evidence must reach and be used by decision-makers. Sharing our findings with peers, policymakers, and the public is essential for creating lasting change.

TOOLS AND RESOURCES

\section{5}

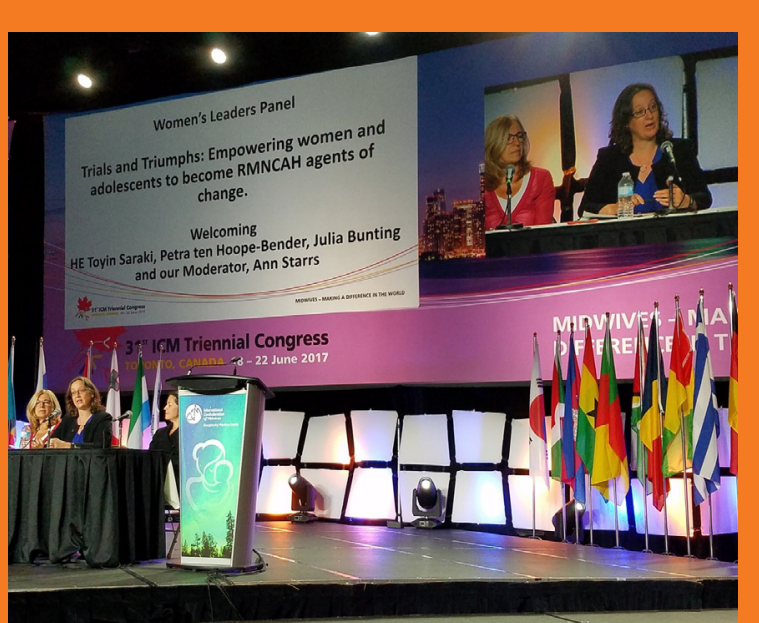

PEER-REVIEWED

PUBLICATIONS

1,416 MEDIA AND

NEWS MENTIONS IN 58 COUNTRIES

653,848 RESOURCE DOWNLOADS

\section{CITED AND DISCUSSED}

Men Will Soon Test a Sperm-Stopping Gel for Birth Control

Researchers like Sitruk-Ware think views are

changing, and that men, especially younger men, will be open to using a contraceptive drug. "This is about gender equity," she says "Men would also like to be able to regulat their own fertility and not be forced into

fatherhood."

\section{MIT}

Technology

Review

HIV and Disabilities: Time for More and Better Data

Despite progress in understanding what puts people with disabilities at increased risk for HIV, this population is still often overlooked

by HIV prevention, care, and treatment

programmes.

\section{THE LANCET}

HIV
The Incidence of Abortion and Unintended Pregnancy in India, 2015

The new estimates of incidence of abortion

and unintended pregnancy in India will

hopefully motivate and guide policies and programmes to improve the provision of abortion services and contraceptive care.

\section{THE LANCET}

Global Health

How Chickens and Goats Are Helping to Stop Child Marriage

One misperception is that child marriage is an intractable practice," says Annabel Erulkar, a social scientist at the Population Council. "My experience is that communities are quite open to change," she says, "especially when they are presented with better alternatives."

\section{n p r}

\section{(1)}

\section{PUBLIC RECOGNITION}

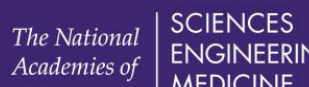

ANN BLANC, invited to Committee on Population of the National Academy
of Sciences

\section{Rotary

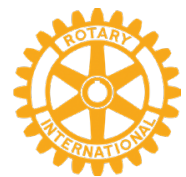

JOHN BONGAARTS, invited lecturer at the Pontifical Academy of Sciences
JHN TOWNSEND, awarded Nafis Sadik Award from the Rotary International Action Group on
Population and Development

120 UNDER 40: THE NEW GENERATION OF FAMILY PLANNING LEADERS

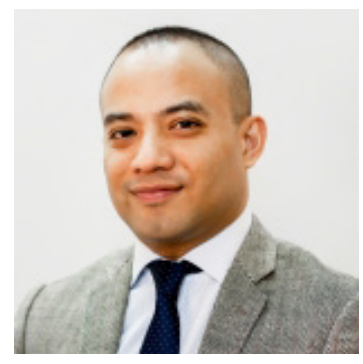

ASHISH BAJRACHARYA, Associate and Cambodia Country Representative

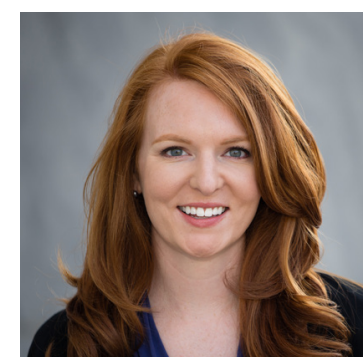

ELSPETH WILLIAMS, Associate Director, Policy and Government Relations

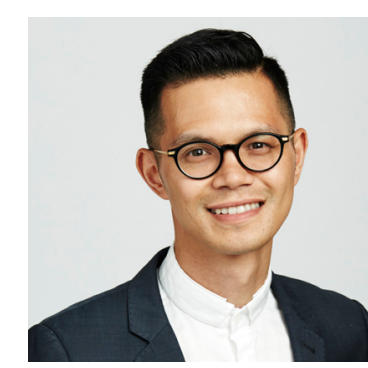

THOAI NGO, Program Director Poverty, Gender, and Youth 


\section{FINANCES}

STATEMENT OF ACTIVITIES (For the year ended December 31, 2017)

\begin{tabular}{|c|c|c|c|c|c|c|}
\hline & \multicolumn{3}{|c|}{ Unrestricted } & \multicolumn{2}{|c|}{ Restricted } & \multirow[b]{2}{*}{ Total } \\
\hline & $\begin{array}{r}\text { General } \\
\text { undesignated }\end{array}$ & $\begin{array}{l}\text { The John D. } \\
\text { Rockefeller 3rd } \\
\text { Memorial Fund } \\
\text { and others }\end{array}$ & Total & $\begin{array}{r}\text { Temporarily } \\
\text { restricted }\end{array}$ & $\begin{array}{r}\text { Permanently } \\
\text { restricted }\end{array}$ & \\
\hline \multicolumn{7}{|l|}{ OPERATING REVENUE } \\
\hline Grants and contributions & $\$ 70,352,420$ & 1,000 & $70,353,420$ & $1,410,716$ & - & $71,764,136$ \\
\hline Royalties & $10,960,758$ & - & $10,960,758$ & - & - & $10,960,758$ \\
\hline $\begin{array}{l}\text { Interest and dividends (net of } \\
\$ 185,022 \text { investment fees) }\end{array}$ & 146 & $1,290,813$ & $1,290,959$ & 260,319 & - & $1,551,278$ \\
\hline $\begin{array}{l}\text { Net appreciation in fair value } \\
\text { of investments }\end{array}$ & $(8,569)$ & $10,421,902$ & $10,413,333$ & $2,037,352$ & - & $12,450,685$ \\
\hline Other & 78,067 & - & 78,067 & - & - & 78,067 \\
\hline Net assets released from restrictions & s $1,062,294$ & - & $1,062,294$ & $(1,062,294)$ & - & - \\
\hline TOTAL OPERATING REVENUE & $82,445,116$ & $11,713,715$ & $94,158,831$ & $2,646,093$ & - & $96,804,924$ \\
\hline \multicolumn{7}{|l|}{ OPERATING EXPENSES } \\
\hline \multicolumn{7}{|l|}{ Program services } \\
\hline Social \& behavioral sciences & $55,552,271$ & - & $55,552,271$ & - & - & $55,552,271$ \\
\hline Biomedical research & $10,009,697$ & $7,613,581$ & $17,623,278$ & - & - & $17,263,278$ \\
\hline TOTAL PROGRAM SERVICES & $65,561,968$ & $7,613,581$ & $73,175,549$ & - & - & $73,175,549$ \\
\hline \multicolumn{7}{|l|}{ Supporting services } \\
\hline Management and general & $12,432,962$ & 130,313 & $12,563,275$ & - & - & $12,563,275$ \\
\hline Fundraising & 680,350 & - & 680,350 & - & - & 680,350 \\
\hline TOTAL SUPPORTING SERVICES & $13,113,312$ & 130,313 & $13,243,625$ & - & - & $13,243,625$ \\
\hline TOTAL OPERATING EXPENSES & $78,675,280$ & $7,743,894$ & $86,419,174$ & - & - & $86,419,174$ \\
\hline $\begin{array}{l}\text { Excess of operating revenue } \\
\text { over operating expenses }\end{array}$ & $3,769,836$ & $3,969,821$ & $7,739,657$ & $2,646,093$ & - & $10,385,750$ \\
\hline \multicolumn{7}{|l|}{ Other changes in net assets } \\
\hline $\begin{array}{l}\text { Loss on lease obligation and other, } \\
\text { net }\end{array}$ & (72) & - & (72) & - & - & (72) \\
\hline $\begin{array}{l}\text { Pension and other postretirement } \\
\text { charges other than net periodic } \\
\text { benefit cost }\end{array}$ & $(853,366)$ & - & $(853,366)$ & - & - & $(853,366)$ \\
\hline Transfer from endowments & $(2,848,371)$ & ) $3,529,605$ & 681,234 & $(681,234)$ & - & - \\
\hline INCREASE IN NET ASSETS & 68,027 & $7,499,426$ & $7,567,453$ & $1,964,859$ & - & $9,532,312$ \\
\hline $\begin{array}{l}\text { NET ASSETS AT BEGINNING } \\
\text { OF YEAR }\end{array}$ & $1,676,188$ & $72,064,882$ & $73,741,070$ & $10,844,676$ & $5,485,776$ & $90,071,522$ \\
\hline NET ASSETS AT END OF YEAR & $\$ 1,744,215$ & $79,564,308$ & $81,308,523$ & $12,809,535$ & $5,485,776$ & $99,603,834$ \\
\hline
\end{tabular}

12 | POPULATION COUNCIL
BALANCE SHEET (For the year ended December 31, 2017)

\section{ASSETS}

Cash and cash equivalents

$\$ 8,220,936$

Grants and contributions receivable, net

$\begin{array}{lr}\text { U.S. government agencies } & 8,263,170 \\ \text { Other } & 6,778,814\end{array}$

Other receivables

822,774

$\begin{array}{lr}\text { Prepaid expenses and other assets } & 1,729,958\end{array}$

Investments 102,971,232

$\begin{array}{lr}\text { Fixed assets, net } & 12,116,891 \\ & \\ \text { TOTAL ASSETS } & 140,903,775\end{array}$

\section{LIABILITIES AND NET ASSETS}

Liabilities

\begin{tabular}{lr} 
Accounts payable, accrued expenses, and other liabilities & $\$ 4,939,680$ \\
Awards, contracts, and fellowships payable & $6,283,463$ \\
Program advances & $12,813,832$ \\
Deferred revenue & - \\
Loans payable & $5,369,946$ \\
Deferred rent credit & $5,285,743$ \\
Accrued lease obligation & 106,091 \\
Postretirement medical benefits payable & $6,501,186$ \\
\hline OTAL LIABILITIES & $41,299,941$
\end{tabular}

TOTAL LIABILITIES

$41,299,941$

Net assets

\begin{tabular}{lr} 
Unrestricted & \\
$\quad$ General undesignated & $1,744,215$ \\
The John D. Rockefeller 3rd Memorial Fund and others & $79,564,308$ \\
\cline { 2 - 2 } SUBTOTAL UNRESTRICTED & $81,308,523$ \\
Restricted & \\
$\quad$ Temporarily restricted & $12,809,535$ \\
$\quad$ Permanently restricted & $5,485,776$ \\
OTAL NET ASSETS & $99,603,834$ \\
\hline OTAL LIABILITIES AND NET ASSETS & $\$ 140,903,775$
\end{tabular}

A copy of the audited financial statements, prepared in accordance with U.S. generally accepted accounting principles, is available upon request from Population Council, One Dag Hammarskjold Plaza, New York, New York 10017, and can be accessed online at popcouncil.org. 


\section{OUR SUPPORTERS}

The Population Council is grateful to each of our donors, whose generosity makes our work possible. Funding for the Population Council's work was provided by government agencies, multilateral organizations, foundations, corporations, and individuals. We value our longstanding relationships with many of these donors and welcome the support from new ones. Their

commitment allows the Council to deliver solutions to critical health and development challenges and improve lives.

GOVERNMENTS AND IS AND Government of Canada - Global Affairs Canada Government of the
Netherlands

- Ministry of Foreign Affairs Government of Norway - Norwegian Agency for Development
(NORAD)

Government of Sweden Swedish International
Development Cooperation Development Co
Agency (SIDA)

Government of the United

Kingdom

- Department for International
Development (DFID) avernment of the United

- Agency for Internationa Development (USAID) Control and Prevention (CDC)

National Institutes of Health $(\mathrm{NIH})$

MULTILATERAL International Labour Organization (ILO) United Nations Children's Fund (UNICEF)

United Nations Educational, Scientific and Cultural Organization (UNESCO) United Nations Entity for Gender Equality and the (UN Women)
United Nations Population World Bank Group (WHO)

\section{DUNDATIONS} TORPORATIONS/OTHER NONGOVERNMIENTAL ORGANIZATIONS

Anonymous (2)

Abt Associates Inc.

ga Khan Foundation AmazonSmile Foundation American Jewish World

America's Best Local Charities Aspen Airport Busines Astor Travel/Tzell Trave Avenir Health

The Avis and Clifford Barrus Medical Foundation The Batonga Foundation The Benevity Community Impact Fund

The Boeing Company Gift Matching Program (BPAC) The Bridgespan Group Carl Marks \& Co. Colliers International NY LLC Columbia University Medica Inc.

(CMT)
Communty Media Trust
Comunidades de la Tierra Concept Foundation The Dawn Hill Fund Deutsche Gesellschaft Zur internationale Zusarion

Johns Hopkins University EngenderHealth

Financial Decisions, LLC The Ford Foundation

Zukunft der Arbeit Gmb The Bill \& Melinda Gates Glasswing International Global Health Corps (GHC) Guttmacher Institute Hamilton \& Company Health Decisions

H\&M Hennes \& Mauritz The William and Flora Hewlett Found

Fred Hutchinson Cance Research Center

ndependent Charities of America/Health \& Medic Research

Institute of Internationa

Education (IIE)

International Development Research Centre (IDRC) International Initiative for Impact Evaluation (3ie) International Planned
Parenthood Federation Paren
(IPPF)
International Rescue mistion. Antinor, s. Henry M. Jackson
Foundation for the Advancement of Military Medicine JSI Research \& Training ustgive.org

Kaiser Foundation Health Plan of the Northwest Community

The W. K. Kellogg Foundation KPMG

Los Angeles Biomedical Research Institute at Harbor-UCLA

John D. and Catherine T. MacArthur Foundation

Magee-Women's Research Institute and Foundation

Maryland Charity Campaign National Agency for the Control Network For Good Nike Found

Nivi, Inc.

Nossal Institute Limited

NoVo Foundation

The Oak Foundation

The David \& Lucile Packard Foundatio

Play For Your Cause

Population Services and
Training Centre, Pakistan Training Centre, Pakistan PATH

\begin{tabular}{|c|c|c|c|}
\hline $\begin{array}{l}\text { Project Concern } \\
\text { International }\end{array}$ & $\begin{array}{l}\text { INDIVIDUAL } \\
\text { DONORS AND }\end{array}$ & $\begin{array}{l}\text { COUNCIL } \\
\text { INNOVATORS }\end{array}$ & $\begin{array}{l}\text { Wayne Bartz } \\
\text { Margaret Battin }\end{array}$ \\
\hline $\begin{array}{l}\text { Public Health Foundation of } \\
\text { India (PHFI) }\end{array}$ & FAMILY FOUNDATIONS & $\begin{array}{l}\text { George P. Cernada } \\
\text { Michelle Cuccia }\end{array}$ & Gary Baxel \\
\hline $\begin{array}{l}\text { India (PHII) } \\
\text { Reproductive Health Supplies }\end{array}$ & JOHN D. ROCK & & Carolyn Beavert \\
\hline Coalition (RHSC) & VISIONARIES & $\begin{array}{l}\text { Barbara B. Ebert } \\
\text { Sallie Gouverneur }\end{array}$ & \\
\hline $\begin{array}{l}\text { Research Foundation of the } \\
\text { City University of New York }\end{array}$ & $\begin{array}{l}\text { Anonymous } \\
\text { Willard B. Brown }\end{array}$ & Victor Halberstadt & Janice Beglau-Taylor \\
\hline $\begin{array}{l}\text { Rockefeller Philanthropy } \\
\text { Advisors (RPA) }\end{array}$ & $\begin{array}{l}\text { Jerry and Diane } \\
\text { Cunningham }\end{array}$ & $\begin{array}{l}\text { John and Jeanet Irwin } \\
\text { The Kaplan Sisters }\end{array}$ & $\begin{array}{l}\text { Ernest Bell } \\
\text { Jolanta Benal }\end{array}$ \\
\hline Rozan & The Edlow Family & Foundation & Caleb Benedict \\
\hline Rutgers Pakistan & Millstream Fund Inc. & $\begin{array}{l}\text { Nirvana Manana } \\
\text { Institute }\end{array}$ & Neil Bennett \\
\hline $\begin{array}{l}\text { The Sackler Institute for } \\
\text { Nutrition Science }\end{array}$ & $\begin{array}{l}\text { Theodore and Iracy } \\
\text { Spencer }\end{array}$ & $\begin{array}{l}\text { Terry Peigh and Cindy G. } \\
\text { Fluxgold }\end{array}$ & $\begin{array}{l}\text { William G. and Marie L. } \\
\text { Blakney } \\
\text { Ann Blanc }\end{array}$ \\
\hline Save the Children & $\begin{array}{l}\text { Valerle larico and Brian } \\
\text { Arbogast }\end{array}$ & $\begin{array}{l}\text { Nicolas and Jeanne } \\
\text { Greenbers Rohatyn }\end{array}$ & $\begin{array}{l}\text { Ann Blanc } \\
\text { Caroline Bledsoe }\end{array}$ \\
\hline $\begin{array}{l}\text { Society for Family Health } \\
\text { (SFH) Nigeria }\end{array}$ & $\begin{array}{l}\text { Sukey Wagner } \\
\text { Elizabeth and Jaime }\end{array}$ & $\begin{array}{l}\text { Greenberg Ronatyn } \\
\text { Marc L. and Stacey } \\
\text { Saiontz }\end{array}$ & $\begin{array}{l}\text { Ann Marie Bonardi and } \\
\text { Salvatore Marras }\end{array}$ \\
\hline $\begin{array}{l}\text { SRI International } \\
\text { State of North Carolina }\end{array}$ & Zobel de Ayala & $\begin{array}{l}\text { Saiontz } \\
\text { Seymour and Kate }\end{array}$ & $\begin{array}{l}\text { John and Zenaida } \\
\text { Bongaarts }\end{array}$ \\
\hline The Summit Foundation & PRESIDENT'S LAUREATES & Wei & $\begin{array}{l}\text { Bongaarts } \\
\text { Jane K. Boorstein }\end{array}$ \\
\hline SunTrust Foundation & Anon & COUNCIL FRIENDS & Douglas H. Borsom \\
\hline $\begin{array}{l}\text { Tinker Foundation } \\
\text { UBS Financial Services }\end{array}$ & $\begin{array}{l}\text { Darcy Bradbury and Eric } \\
\text { Seiler }\end{array}$ & Anonymous & $\begin{array}{l}\text { David N. and Harriet B. } \\
\text { Borton }\end{array}$ \\
\hline $\begin{array}{l}\text { Inc. } \\
\text { Univer }\end{array}$ & $\begin{array}{l}\text { Julia Bunting and Barrie } \\
\text { Thring }\end{array}$ & $\begin{array}{l}\text { Charles C. Abele } \\
\text { David Abrams }\end{array}$ & $\begin{array}{l}\text { John W. and Claire M. } \\
\text { Bossung }\end{array}$ \\
\hline Diego (UCSD) & $\begin{array}{l}\text { Head Family Charitable } \\
\text { Foundation }\end{array}$ & $\begin{array}{l}\text { Donald J. and Dena C. } \\
\text { Abrams }\end{array}$ & Leslie Brandon \\
\hline $\begin{array}{l}\text { University of California San } \\
\text { Francisco (UCSF) }\end{array}$ & Kyung J. Kim & $\begin{array}{l}\text { Brian Adams } \\
\text { Diane Adams }\end{array}$ & $\begin{array}{l}\text { Anita and Barney } \\
\text { Brannen }\end{array}$ \\
\hline $\begin{array}{l}\text { University of Connecticut } \\
\text { Health Center }\end{array}$ & $\begin{array}{l}\text { E. Wayne Nordberg } \\
\text { Robertson Foundation }\end{array}$ & Richard Adler & $\begin{array}{l}\text { Deborah G. and Mic } \\
\text { G. Branton }\end{array}$ \\
\hline University of Pittsburgh & Shenandoah Foundation & Mohammad Ahmad & Germán A. Bravo-Casas \\
\hline U.S. Coffee & & Alok and Nina Ahuja & Bridgewood Fieldwater \\
\hline $\begin{array}{l}\text { Wits Reproductive Health \& } \\
\text { HIV Institute }\end{array}$ & CHAMPIONS & $\begin{array}{l}\text { George Ainslie } \\
\text { Martha Ainsworth }\end{array}$ & $\begin{array}{l}\text { Foundation } \\
\text { Christopher N. Brown }\end{array}$ \\
\hline $\begin{array}{l}\text { Vanguard Charitable } \\
\text { Endowment Program }\end{array}$ & $\begin{array}{l}\text { lammy Allen and Dan } \\
\text { Gropper }\end{array}$ & $\begin{array}{l}\text { Shirley Alexander } \\
\text { Laura Allen }\end{array}$ & $\begin{array}{l}\text { Trudy B. Brown } \\
\text { Frederick Buckner }\end{array}$ \\
\hline $\begin{array}{l}\text { Van Ness Center Associates, } \\
\text { LLC }\end{array}$ & $\begin{array}{l}\text { D.E. and Angelica Baird } \\
\text { Peter Brandt and Laura } \\
\text { Burwick }\end{array}$ & $\begin{array}{l}\text { Timothy S. and Anne M. } \\
\text { Allen }\end{array}$ & $\begin{array}{l}\text { Andrew Bundy } \\
\text { Gemma Bush }\end{array}$ \\
\hline Yale University & Wanda J. Olson & Joyce and Billy Altman & Ann J. Cahill \\
\hline Your Cause & Xixi and Jonathan & $\begin{array}{l}\text { Linda Andes-Georges and } \\
\text { Jean-Pierre Geores }\end{array}$ & Cathy Cai \\
\hline ZanaAfrica Group & Shakes & Mary Andrews & Caithness Foundation, \\
\hline ZogSports DC & $\begin{array}{l}\text { Mark A. and Tania } \\
\text { Walker }\end{array}$ & Marley Arborico & $\begin{array}{l}\text { Inc. } \\
\text { Frieda R. Caplan }\end{array}$ \\
\hline & $\begin{array}{l}\text { Rena Zieve and Greg } \\
\text { Kuperberg }\end{array}$ & $\begin{array}{l}\text { Michael Baird } \\
\text { Nancy L. Balch }\end{array}$ & $\begin{array}{l}\text { Elizabeth Cashen } \\
\text { William W. Chadwi }\end{array}$ \\
\hline & & Margaret E. Bancroft & Richard Chasin \\
\hline & & $\begin{array}{l}\text { Jonathan and Judith } \\
\text { Baron }\end{array}$ & $\begin{array}{l}\text { Nachela Chelwa } \\
\text { Michele M. Clancy }\end{array}$ \\
\hline & & Marilyn Barton & Jeanne Clelland \\
\hline
\end{tabular}


OUR SUPPORTERS

\begin{tabular}{|c|c|c|c|}
\hline $\begin{array}{l}\text { J. W. Cliett } \\
\text { William W. Cobbs, Jr. }\end{array}$ & $\begin{array}{l}\text { Robert Gillespie } \\
\text { Eitan Glinert }\end{array}$ & $\begin{array}{l}\text { Holiday S. and Philip A. } \\
\text { Houck }\end{array}$ & $\begin{array}{l}\text { Arthur and Eva Landy } \\
\text { Brian L. Larson }\end{array}$ \\
\hline Edward M. Cohen & Carey Goldberg & Frederick G. Hughes III & Robert M. and Ruth C. \\
\hline $\begin{array}{l}\text { Laurie and Michael } \\
\text { Constantino }\end{array}$ & Rachel E. Goldberg & $\begin{array}{l}\text { Valerie and Terry Hull } \\
\text { William P. Huxley }\end{array}$ & $\begin{array}{l}\text { Law } \\
\text { Fred and Juanita Leonard }\end{array}$ \\
\hline Harold and Cynthia Cook & $\begin{array}{l}\text { Elaine R. Goldman } \\
\text { Elizabeth Goodson }\end{array}$ & $\begin{array}{l}\text { Willam P. Huxley } \\
\text { Frederick V. Iffert }\end{array}$ & $\begin{array}{l}\text { Fred and Juanita Leonard } \\
\text { Jack G. Levine and }\end{array}$ \\
\hline David E. Cowles & Marc and Carol Gordon & Jeanne Imai & Jeanette W. Melley \\
\hline George and Jane Creasy & Gorlitz Foundation, Ltd. & Anna Irwin & Susan Levine \\
\hline $\begin{array}{l}\text { Christopher S. and Karen } \\
\text { H. Cronan }\end{array}$ & $\begin{array}{l}\text { Susan W. Granger } \\
\text { Anita Grath }\end{array}$ & $\begin{array}{l}\text { Kenneth and Priscilla } \\
\text { Jamieson }\end{array}$ & $\begin{array}{l}\text { Katherine Lewis } \\
\text { Jeffrey Lichtman }\end{array}$ \\
\hline Roberto Cuca & David Grill & Alice Jena & Linda E. and Jason A. \\
\hline Vanessa Cullins & Nancy J. Gunther & Monwhea Jeng & Lillegraven \\
\hline Arthur J. Curtze & Marjorie Gustafson & Mark S. Jenne & Martin and Rhoda Sue \\
\hline Louis Dana & Lisa Gustavson and & Jewish Communal Fund & Lonow \\
\hline Kay Davis & Christopher Sales & Richard Johnson & Joanne Lyman \\
\hline Noel de Nevers & Anke and Peter & Andreas Jones & Beau Lynn-Miller \\
\hline Sarah de Tournemire & Haberland & Peter Joyce & $\begin{array}{l}\text { John C. and Barbara M. } \\
\text { Lynskey }\end{array}$ \\
\hline Mary H. Dodge & Nicole Haberland & Robert Joyce & Walter and Ruth \\
\hline $\begin{array}{l}\text { Stanley F. and Elizabeth } \\
\text { S }\end{array}$ & Scott Haese & Karl A. and Carmen & MacGinitie \\
\hline $\begin{array}{l}\text { G. Dole } \\
\text { Carey W. and Judith } 0 . \\
\text { Donaldson }\end{array}$ & $\begin{array}{l}\text { Robert Haines } \\
\text { Robert Metcalf Hall, Jr. }\end{array}$ & $\begin{array}{l}\text { Jungobuth } \\
\text { J. E. Juterbock } \\
\text { Jonathan and Ute Kagan }\end{array}$ & $\begin{array}{l}\text { Doug MacMillan } \\
\text { Erik Maehlmann }\end{array}$ \\
\hline Peter J. Donaldson & $\begin{array}{l}\text { Elizabeth Hallin } \\
\text { Susan Hargrave }\end{array}$ & $\begin{array}{l}\text { Jonathan and Ute Kagan } \\
\text { Martin Kahn }\end{array}$ & Carolyn Makinson \\
\hline Brigitte Driller & $\begin{array}{l}\text { Susan Hargrave } \\
\text { Katharine Harkins }\end{array}$ & Eugene Kaplan & Rita Malkki \\
\hline George Dudley & Aljean and Richard S. & James A. Kaplan & $\begin{array}{l}\text { Roger and Isabel } \\
\text { Marchese }\end{array}$ \\
\hline Zora Ann Ellis & Harmetz & Marion S. Kaplan & $\begin{array}{l}\text { Marchese } \\
\text { Kenneth Marsalek }\end{array}$ \\
\hline Wafaa El-Sadr & Guy Harris & Barry Karlin & \\
\hline Andrea Eschen & Polly Harrison & Mike Keating & Katharine Marvin \\
\hline $\begin{array}{l}\text { Donna J. Evans } \\
\text { Chet Fagin }\end{array}$ & Shannon Harvey & $\begin{array}{l}\text { Deborah L. and Richard } \\
\text { A. Keefe }\end{array}$ & Joel W. and Patricia A. \\
\hline $\begin{array}{l}\text { Chet Fagin } \\
\text { Colter Fairman }\end{array}$ & $\begin{array}{l}\text { William G. and Caroline } \\
\text { K. Hatton }\end{array}$ & $\begin{array}{l}\text { A. Keefe } \\
\text { Steven Keleti }\end{array}$ & $\begin{array}{l}\text { Marx } \\
\text { John Matzger }\end{array}$ \\
\hline $\begin{array}{l}\text { H. K. and Nancy W. } \\
\text { Faulkner }\end{array}$ & $\begin{array}{l}\text { Dirk F. and Dixie R. } \\
\text { Havlak }\end{array}$ & $\begin{array}{l}\text { John E. Kester } \\
\text { Charles W. Kettering }\end{array}$ & Peter J. Mayer \\
\hline Rosemary Faulkner & Thomas C. Hayes & Hye In Kim & Downs McCloskey \\
\hline Glen M. Feighery & Stephen F. Heartwell & $\begin{array}{l}\text { Hye In KIm } \\
\text { Lisa King }\end{array}$ & Elizabeth J. McCormack \\
\hline Bruce and Daria Fireman & Albert Hermalin & A. Larkin Kirkman & Christopher McDonough \\
\hline Matthew J. Fortune & James F. Herndon & Margaret A. Knoll & Hugh McGaughy \\
\hline $\begin{array}{l}\text { Edward Foulke and } \\
\text { Caroline F. Wetters }\end{array}$ & Elizabeth-Ann Herrick & Richard Koch & $\begin{array}{l}\text { Geoffrey McNicoll } \\
\text { Joan Meerman }\end{array}$ \\
\hline $\begin{array}{l}\text { Caroline F. Wettersten } \\
\text { James Fraser }\end{array}$ & Judith Herzfeld & Ted Koerner & Michelle and Rolf J. \\
\hline James Fraser & Susan J. Hessel & KPMG & Mehlhorn \\
\hline Edward Friedman & William Hildreth & $\begin{array}{l}\text { Elliott and Sharon P. } \\
\text { Krefetz }\end{array}$ & Barbara S. Mensch \\
\hline $\begin{array}{l}\text { Gary and Kristin } \\
\text { Friedman }\end{array}$ & $\begin{array}{l}\text { John Hirschi } \\
\text { Edward S. Hochman }\end{array}$ & $\begin{array}{l}\text { Krefetz } \\
\text { Wayne V. Krill }\end{array}$ & Lauren Meserve \\
\hline Sheryl P. Gardner & Douglas Holdridge & $\begin{array}{l}\text { Wayne V. Krill } \\
\text { George Krumme and }\end{array}$ & Aviva Klein Meyers \\
\hline Lydia Garvey & Paula Hollerbach & $\begin{array}{l}\text { George Krumme and } \\
\text { Aldean Newcomb }\end{array}$ & Rachel Michels \\
\hline Sigmund Gast & Frederick W. Hollmann & Vivian Kuperberg & Barbara Miller \\
\hline Michele Gerber & Edith Hoogenboom & Joel Kurtzberg & Donald B. Miller \\
\hline Leslie Giering & Diane Hopkins & Maria Jimena Del Aguila & Maureen Milligan \\
\hline Mark M. Giese & & Lacoste & sentiner vinte \\
\hline
\end{tabular}

\begin{tabular}{l} 
John Mirsky \\
Samarendranath Mitra \\
Colin Monaghan \\
Katharine B. Morgan \\
Courtney Morris \\
John Morris \\
Lloyd N. and Mary P. \\
Morrisett \\
Scott B. Mouw \\
Ann Naftel \\
Charles B. Nam \\
Leroy and Anita L. \\
Nelson \\
Thoai Ngo \\
Enmei Niu \\
Roger and Joyce \\
Nussbaum \\
John Ochs \\
William E. O'Connor \\
Lynn F. OIson \\
David and Laura \\
Osterman \\
Robert H. and Jessie \\
Palmer \\
Katherine Pannell \\
Loretta Parsons \\
Diane Pascal \\
Jeffrey J. Passel \\
Michelle Patterson \\
Kirstie Paul \\
Daniel K. and Susan A. \\
Paulien \\
Tomas J. Pavel \\
Anne R. Pebley \\
Jessica G. Perri \\
Eugene W. Peterson \\
Clyde C. Phillips, III \\
Mary Phinney \\
Linda Pierce \\
David Porteous and \\
Vicky Smith \\
Ann Pugh \\
Joelle Raichle \\
Lauren Rankin \\
John P. and Brenda L. \\
Raphael \\
Habib Rathle \\
Apurba K. and Krishna \\
Ray \\
\hline
\end{tabular}

Ray

Bayard D. Rea
Phillip F. and Andrea
Reid
Warren R. and Nancy J.
Reinecke
Jeffrey Rhodes
David S. Rice
Eve Rice
Thomas L. Richie and
Diane Pascal
Amy Riddle
Eleanor Rieffel
Julie Robichaud
Mordecai Rochlin
Justin A. Rockefeller
Beth Roemer
Charles S. and Evelyn
S. Rose
Marilyn Rosenblatt
Ken Ross
Shelley Roth and Jed
Weissberg
Lorenzo A. and Anita G.
Sadun
Lawrence Safran
Gloria Sage
James E. Sailer and Cass
Conrad
Leslie Samuels
Ariel Santos
Karen P. Schaefer
Nancy J. Schieffelin
Frederick H. Schmidt
John Schmidt
Steven Schmitt
Brian Schneidewind
Richard Schultz
Jutta R. Scott
Leslie Scott
Harriet Segal
Kathryn Segal
Akash Sehgal
Marianne E. Selph
Nandana Sen
Cynthia L. and Michael
D. Sevilla
G.E. and Joyce Shissler
Daniel Shively
Brian Short

H. K. Sinclair

Peter Sinclaire

Cherida Collins Smith

Michael C. and L. Linda

Richard D. Smith and

Joanne P. Smith

Jeffrey Spieler

Virginia Stearn

Karen Steel

Hilde Stempel

Sue Stewart

Katy R. Stokes and

Dhomas Storm

Bertram and Lynne Y.

Yaping $S$

John K. and Elizabeth A.

Sullivan

Te-Hsiung Sun

Alan S. and Danna Taylor

Michael Todd

tacqueline Togut

Arlene Torres

John and Judy Townsend

Roy Treadway

Amy Ong Tsui

David G. and Kathy Van

Dame

Peter W. Vaughan

Michael Vodt

Stephen A. and Yvonne

Tim Walter

Jordan D. and Nicole

Warshaw

Diana K. Weatherby

Peter A. Weida

Barbara F. Wells

Virginia Widstrom

Paul Winder

. K. Winslow

Ellen Wisdom and
Robert L. Griswold

oliver and Helen $\mathrm{M}$.

Wolcott

Warren Wong
Gooloo S. and Gene Wunderich

Chang Po Yang

Barbara Yann

Jerrold Yos

Alice M. Young

Boniface Zaino

Jerrold H. and Carol B.

H. Ziegenfuss

Richard Zigmond

H. N. Zimmerman

Xuejin Zuo

Paul L. and Suzanne 
BOARD OF TRUSTEES

Darcy Bradbury

The D.E. Shaw

Zulfiqar A. Bhutta

Robert Harding Chair in Global

Child Health \& Policy and

Founding Director of the Centre for Excellence in Women and

Child Health

Hospital for Sick Children and Th Aga Khan University

Pakistan

Peter Brandt

nnecticut

\section{Julia Bunting}

President

Population Council

Anna Glasier

Honorary Professo

Department of Obstetrics and

Gynecology

University of Edinburgh

Edinburgh, United Kingdom

Victor Halberstadt

Professor of Public Sector

Economics

Netherlands

Jonathan Kagan

Managing Principal

New York, New York

\section{Salim S. Abdool Karim}

Director

Centre for the AIDS Programme

of Research in South Afric

Cape Town, South Africa

\section{Cheikh Mback}

Independent Consultan

Dakar, Senegal

\section{Lauren A. Meserve}

Chief Investment Officer

New York, New York
Wanda Olson

Senior Counsel

Cleary Gottlieb Steen \&

Hamilton LLP

Terry Peigh

Senior Vice President,

preblic Group of Companies

New York, New York

K. Sujatha Rao

New Delhi, India

\section{Jonathan Shakes}

.

Mercer Island, Washington

Theo Spencer

Natural Resources Defense

Council

New York, New York

Jeffrey M. Spieler

Senior Technical Advisor for

Science and Technology

Office of Population and RH,

USAID/W at IAP World Services

Baltimore, Maryland

\section{Kaye Wellings}

Professor of Sexual and

Rondon School of Hysient

Tropical Medicine

ondon, United Kingdom

\section{President}

Ann K. Blanc

Vice President

Social and Behavioral Science Research

\section{John Bongaarts}

Distinguished Schola

Jackson Ireland

Vice President for Corporate

Finance and Administration

James E. Sailer

Vice President and Executive

Der for Biomedical Research

\section{Sarah de Tournemire}

Vice President of Development and Engagement

General Counsel and Secretary
POPULATION COUNCIL OFFICES

\section{UNITED STATES}

Headquarters

e Dag Hammarskjold Plaza

New York, NY 10017 USA

Fax +12127556052

E-mail pubinfo@popcouncil.org

Center for Biomedical Research

Population Counci

New York, NY 10065 USA

Tel +1 2123278731

Fax +1 2123277678

E-mail biomed@popcouncil.org

Washington, DC

4301 Connecticut Avenue, NW

Washington, DC 20008 USA

Fax +1 2022378410

E-mail popcouncil@popcouncil.org

\section{INTERNATIONAL}

\section{Banglades}

Gulshan-1, Dhaka, Bangladesh 121

Tel +880-2-984-2276

E-mail info.bangladesh@popcouncil.org

Cambodia

\# 12 Eo. St. 41. Sangkat Tonle Bassac

Phnom Penh, Cambodia

E-mail info.cambodia@popcouncil.or

Egypt

Population Counci

12 El Nahda Street,

Maadi

Cairo, Egypt 11431

Tel $+20-2-2358-2172$

E-mail info.egypt@popcouncil.or
Ethiopia

Population Council

Heritage Plaza, 4th Floor

Bole Medhaneialem Road

Addis Ababa, Ethiopia

Tel + 251-116-631-712

E-mail info.ethiopia@popcouncil.org

Ghana

14B Ridge Road

Roman Ridge

Tel +233-30-2-780711

E-mail info.ghana@popcouncil.org

\section{Guatemala}

Population Counci

Avenida 0-35

Main tel +502-2369-0292

Altrinatel +502-5293-0030

Fax +502-2369-6919

E-mail info.guatemala@popcouncil.o

hala Habitat Centre, Lodi Road

New Delhi, India 110003

Tel +91-11-2-464-2901

E-mail info.india@popcouncil.org

Kenya

Population Counci

Avenue 5

3rd Floor, Rose Avenue

Nairobi, Kenya

Tel +254-20-271-3480

E-mail info.nairobi@popcouncil.or

Population Council

Torre Murano Piso 9 Local 903

Colonia Tizapán,
Álvaro Obregón

Tel +52-55-5999-8630

E-mail info.mexico@popcouncil.or
Nigeria

Council

House 4, No. 16B, POW Mafemi

Crescent, Utako Distric

Abuja, Nigeria

E-mail info nigeria@popcouncil.or

Pakistan

Population Council

3rd Floor, National Telecommunication

Corporation (NTC) Regional

Sector F-5/1

Islamabad, Pakistan

Tel

E-mail info.pakistan@popcouncil.org

Senegal

Population Counc

Sacré Coeur 3 Pyrotechnie

S5 Appartement 2ème Etage à Droite

BP21027 Dakar Ponty, Dakar,

(5engar

Tel +221-33-859-5300

E-mail info.senegal@popcouncil.org

Population Counci

Plot \#3670, No. 4 Mwaleshi Road

Olympia Park

Lusaka, Zambia 10101

Tel +260-211-295925

E-mail info.zambia@popcouncil.org 
The Population Council confronts critical health and development issues-from stopping the spread of HIV to improving reproductive health and ensuring that young people lead full and productive lives. Through biomedical, social science, and public health research in 50 countries, we work with our partners to deliver solutions that lead to more effective policies, programs, and technologies that improve lives around the world. 